
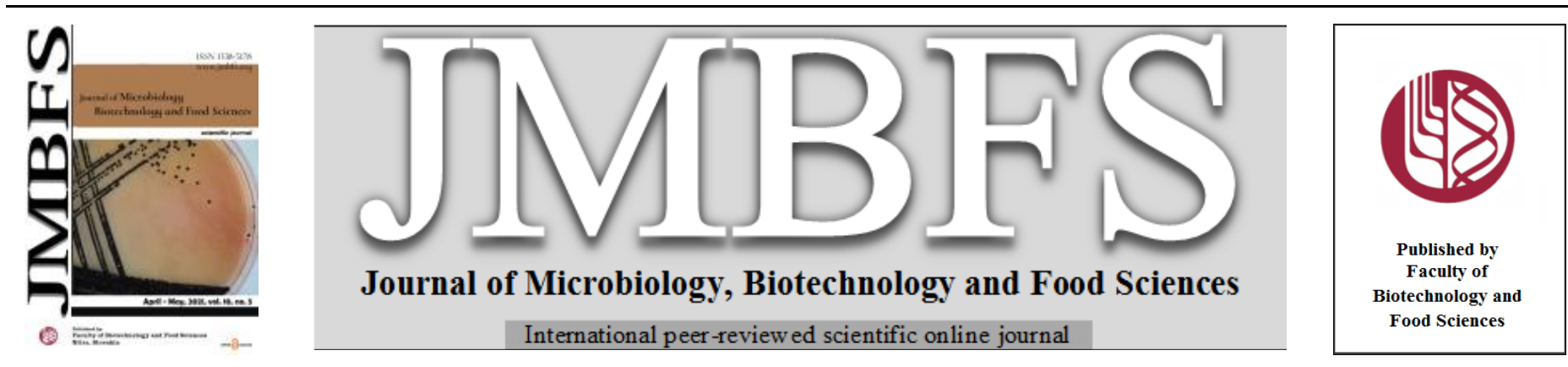

\title{
BIOLUMINOMETRIC ASSAY OF CELL ATP DETECTION UNDER STRESS CONDITIONS AND IN THE ASSESSMENT OF CLEANNESS OF THE FOOD PRODUCING COMPANY
}

\author{
Miroslava Požgajová* ${ }^{1}$, Hana Ďúranová ${ }^{1}$ \\ Address(es): Dr. Ing. Miroslava Požgajová, \\ ${ }^{1}$ AgroBioTech Research Center of the Slovak University of Agriculture in Nitra, Tr. A. Hlinku 2, 94976 Nitra, Slovakia, phone number: +421 376414919.
}

*Corresponding author: miroslava.pozgajova@ uniag.sk

https://doi.org/10.15414/jmbfs.2584

\section{ARTICLE INFO}

Received 23. 1.2020

Revised 9. 12. 2020

Accepted 28. 12. 2020

Published 1. 4. 2021

\section{Regular article}

open Oaccess

\begin{abstract}
Detection and tracking of microorganism's behavior in natural environments and under stressed conditions have been nowadays accelerated by the requirement for the risk assessment associated with environmental contamination. Luminescence-based techniques, for they cost efficiency, fastness, reliability and reproducibility are particularly appropriate for such studies. We used bioluminescence sensing assay to determine ATP levels in the yeast Schizosaccharomyce pombe. Determination of adenosine concentration per cell was assessed in the yeast cells counted prior to the experiment. To test the methodology, model organism was exposed to life-threatening concentration of heavy metals cadmium and nickel for three hours. Afterwards, changes in the ATP levels were detected and compared to the control. Strikingly, our results revealed that such conditions lead to considerable increase in the production of ATP by mitochondria compared to untreated cells. Normal level of ATP in the control increased from the basal $9.92 \times 10^{-16} \mathrm{M}$ to $2.90 \times 10^{-15} \mathrm{M}$ after $\mathrm{Cd}$ exposure and to $7.58 \times 10^{-15} \mathrm{M}$ upon $\mathrm{Ni}$ treatment. The methodology was subsequently used for assessment of cleanness of margarine producing company devices after regular sanitation procedure. Detection of only negligible amount of the ATP signal confirmed good cleaning strategy in the tested food processing company.
\end{abstract}

Keywords: bioluminescence, ATP, Schizosaccharomyces pombe, heavy metal, food processing company

\section{INTRODUCTION}

Foodborne pathogens are very assorted in nature and keep causing major public health problems in different countries of the world. Thus, the detection and enumeration of microorganisms either in foods or on food contact surfaces are important tools of quality control or food safety plans. Conventional methods of pathogen detection largely rely on microbiological and biochemical analyses that are highly accurate but time-consuming, and cost-ineffective (Elegado et al., 2016). Due to microorganism growth in culture media followed by other procedures (such as isolation, biochemical and/or serological identification, and in some cases, subspecific characterization), traditional microbiological methods in food industry may take at least 2-3 days to provide initial results (Bown et al., 2002), and up to more than one week for confirming the specific pathogenic microorganisms (Zhao et al., 2014). Moreover, conventional methods may be limited by their elaborateness (Betts \& Blackburn, 2009), low sensitivity (Lee et al., 2014) and the risk of false negative results for viable non-culturable pathogens (VBNC pathogens) (Jen \& Chen, 2017). In order to prevent spread of infectious diseases, to ensure food safety, leading to public health protection, extensive research has been provided over the last years to invent more rapid and automated approaches of foodborne pathogen detection (Fung et al., 1988; Feng, 2007; Betts \& Blackburn, 2009; Jasson et al., 2010; Law et al., 2015; Zhao et al., 2014; Valderrama et al., 2016; Wang \& Salazar, 2016; Jan et al., 2018). According to the summarized data by Lazcka et al. (2007), rapid detection methods based on biosensors are the fastest growing technologies for pathogen detection compared to PCR, immunology, and gel electrophoresis. Recent advances in bio-analytical sensors have led to the utilization of the ability of certain enzymes to emit photons as a byproduct of their reaction. This phenomenon, known as bioluminescence, is used for cell contamination detection (Mandal et al., 2011). The method is supposed to be the technique giving results in the shortest time (Dostálek \& Brányik, 2005).

\begin{tabular}{|c|c|c|}
\hline D-Luciferin + ATP & $\begin{array}{l}\text { Lucifer } \\
\text { ase }\end{array}$ & Oxyluciferin $+\mathrm{AMP}+\mathrm{PP} i+\mathrm{CO}_{2}+$ \\
\hline$+\mathrm{O}_{2}$ & $\begin{array}{l}\mathrm{M}^{2+} \\
\mathrm{g}^{2+}\end{array}$ & light emission \\
\hline
\end{tabular}

The adenosine triphosphate (ATP) bioluminescence-sensing assay is considered as an extremely effective biosensor; hence ATP is the energy currency of al living microbes and can be used as a rapid indicator of microbial viability (Eed $e t$ al., 2016). During the assay, ATP reacts with luciferin (extracted from the firefly Photinus pyralis) in the presence of the catalyst - luciferase enzyme, and the effect of this ATP-dependent oxidation of the substrate is production of oxyluciferin, carbon dioxide, AMP, inorganic phosphate, and emission of light, recorded by a luminometer (Dostálek \& Brányik, 2005; Syguła-Cholewińska et al., 2014):

Initially, the oxyluciferin is formed in an electronically excited state, and a light quantum is emitted during the transfer of the product to its ground state (Lomakina et al., 2015). The amount of light produced is proportional to the concentration of ATP, and corresponds to the number of microorganisms in the original sample (López-Campos et al., 2012). Commercially available manual or automated luminometers can detect less than $0.1 \mathrm{pM}$ of ATP per cuvette, corresponding to approximately 100 bacterial cells (Dostálek \& Brányik, 2005). Thus, bioluminescence as a rapid method for ATP production can also be employed in cell cytotoxicity determination since ATP serves as the essential immediate donor of energy and is present in all metabolically active cells (Mandal et al., 2011). Regarding this feature, investigation of ATP production by the yeast Schizosaccharomyces pombe ( $S$. pombe) used as model system provides precise outputs representing moles of ATP produced by a single cell. Furthermore, exposure of $S$. pombe cells to heavy metals (nickel, Ni; cadmium, $\mathrm{Cd}$ ) has also been included in our study. The fission yeast $S$. pombe, is often used as an unicellular model system for studies of various biological and physiological processes in eukaryotic cells (Yanagida, 2002) mainly due to its unpretentiousness in cultivation conditions, amenability to genetic manipulations, and regular cell size (Ď́uranová et al., 2019). As the microbial evaluation of industrial surfaces and devices is useful for monitoring the effectiveness of cleaning and disinfection practices, we applied bioluminescence to assume potential microbiological contamination of devices in a food-producing company after regular sanitation process. In general, luminometric methods serve as convenient approach to measure biological contamination, to its greatest advantages belong relative effortless performance, high sensitivity due to low background, wide dynamic range, and cost effectiveness (Branchini \& 
Southworth, 2017). Moreover, the promptness in results acquisition (Cunningham et al., 2011), allows rapid re-washing of contaminated surfaces or equipment in food producing companies, before production again begins (Betts \& Blackburn, 2009).

Current study was thus aimed to determine the ATP mass of defined $S$. pombe cell quantity and its changes after exposure to life-threatening concentrations of $\mathrm{Cd}(1 \mathrm{mM})$ and $\mathrm{Ni}(1 \mathrm{mM})$ to validate the methodology. The method was subsequently applied for demonstration of the cleanness of the margarine producing company devices after sanitary treatment.

\section{MATERIAL AND METHODS}

\section{Cultures of yeast cells}

Schizosaccharomyces pombe (S. pombe) was used in our study as a source for ATP production. Culture of the prototroph $S$. pombe strain (JG15458, kindly provided from Dr. Gregan) was grown in standard YE + 5S (yeast extract + supplements) (Pozgajova et al., 2019) medium overnight at $30^{\circ} \mathrm{C}$ and $150 \mathrm{rpm}$ shaking conditions. On the basis of protein fingerprint, the yeast culture was approved as a pure $S$. pombe culture by matrix-assisted lase desorption/ionization time-of-flight mass spectrometry (MALDI-TOF MS Bruker Daltonics, Bremen, Germany). Briefly, cells from the $1 \mathrm{~mL}$ fresh overnight culture were used for the ethanol-formic acid extraction, covered with $2 \mu \mathrm{L}$ of matrix solution (saturated solution of $\alpha$-cyano-4-hydroxycinnamic acid in $50 \%$ acetonitrile with $2.5 \%$ trifluoroacetic acid; Bruker Daltonics) subsequently dried on air for $15 \mathrm{~min}$. Protein spectrum of the sample was generated by the Biotyper software, version 2.0 (Bruker Daltonics) and analyzed (Duracka et al., 2018)

Exponentially growing cells were exposed to high concentration (1mM) of nicke (Ni) and cadmium (Cd) for 3 hours. Prior to ATP determination, cells were with the use of Neubauer chamber (VWR International $\mathrm{GmbH}$ Graumanngasse 7, 1150 Wien, Austria) counted to evaluate mitochondria activity expressed as ATP production per cell. To determine ATP levels in single-celled eukaryotic organism $5 \times 10^{6}$ cells/well were placed to each well of the 96 well plate in triplicate. RLUs (relative light units) of tested samples were compared to RLU of standardized ATP curves and moles of ATP per sample were calculated.

Swabbing protocol of sample collection of the margarine producing company devices

After standard sanitary cleaning procedure using chloride water, detergent, and steam for sterilization a cleanness of the system devices of the margarine producing company was analyzed. Sterile cotton hygiene swabs with metallic applicator sticks (VWR transport swabs, sterile, Copan Italia S.p.A., Brescia) saturated in ATP free water were used to swab controlled equipment covering an area of $10 \mathrm{~cm}^{2}$. The swab was rotated constantly during swabbing, and each surface was swabbed in two directions ensuring the swab to come in contact with the entire surface area. The cotton applicator was afterwards placed to amies medium containing sterile plastic transport tubes. Sealed tubes and swabs were held on ice until further procedure in the laboratory. The swab was removed from the tube and placed in a sterile eppendorf tube containing $0.3 \mathrm{~mL}$ of ATP-free water. After thorough mixing excess water was squeezed from the swab by pressing it against the tube wall, and the swab was discarded. To white 96 well plates (Thermo Fisher Scientific, Nunc, Denmark) $100 \mu \mathrm{L}$ of each sample were used for ATP detection in triplicate.

\section{Detection of ATP}

Analyses were performed in 96 well plates (white plates) on Glomax Multi+ Combined Spectro-Fluoro Luminometer (Promega Corporation, Madison, WI USA) with the use of Enliten ${ }^{\circledR}$ ATP assay system (Promega Corporation, Madison, WI, USA) commercial kit aimed to detect $10^{-11}-10^{-15} \mathrm{M}$ ATP/sample As the Glomax Multi+ Combined Spectro-Fluoro Luminometer (Promega Corporation, Madison, WI, USA) is equipped with micro-injectors, prior to measurement, $100 \mu \mathrm{L}$ of the Luciferase/Luciferin $(\mathrm{rL} / \mathrm{L})$ reagent was injected to each well containing $100 \mu \mathrm{L}$ of the sample. Results are represented as RLU and ATP content is calculated according to ATP standard curves generated with the use of ATP standards provided by the manufacturer diluted in ATP free water and ranging from concentrations 8 to $0.5 \mathrm{nM}$ ATP. ATP-free water was used as negative control, RLU values equal or lower then RLU values of ATP-free water were assessed as negative (meaning, no contamination detected).

\section{Statistics}

Four replicates were performed for the analysis in each treatment. To determine significance of any acquired differences a Student's $t$ test was used. The limit of statistical significance was set up at $\mathrm{P}<0.05(*), 0.01(* *), 0.001(* * *)$ for all statistical analyses.

\section{RESULTS AND DISCUSSION}

\section{Microbial ATP production}

It has been previously reported, that rapid detection of microbial presence even in very low concentrations is possible via detection of ATP levels with the use of bioluminescence technique (Squirrell et al. 2002). Relation between ATP concentration and determined RLU values was expressed through correlation standard curve with calibration formula RLU $=1011.8 \mathrm{ATP}+82.99\left(\mathrm{r}_{\mathrm{P}}=0.992\right.$ $\mathrm{P}<0.001)$. Determination of ATP concentration of known cell counts in our laboratory conditions is summarized in Table 1.

\section{Table 1 ATP production in yeast Schizosaccharomyces pombe}

\begin{tabular}{cccc} 
S. pombe per mL & cells per well & ATP $[\mathrm{nM}]$ & ATP $[\mathbf{M}]$ per cell \\
\hline $61.5 \times 10^{6}$ & $5 \times 10^{6}$ & $4.96 \pm 0.07$ & $9.92 \times 10^{-16}$ \\
\hline
\end{tabular}

To further test the sensitivity of the used ATP detection method, we exposed the model organism to high concentrations of two different heavy metals, cadmium and nickel, known to interfere with the intracellular homeostatic system.

\section{ATP production under stress conditions}

Cadmium and nickel are heavy metals which have received a great deal of attention not only as potent hazards to human health but also for their nondegradable nature leading to persistence in the environment and bioaccumulation via the food chain (Amari et al., 2017). The effect of $\mathrm{Cd}$ and $\mathrm{Ni}$ on ion homeostasis in $S$. pombe have been assessed in our recent study by Pozgajova $e$ al. (2019). The authors have found that high concentration of applied heavy metals resulted in considerable elevation of $\mathrm{Ca}^{2+}, \mathrm{Na}^{+}, \mathrm{Mg}^{2+}, \mathrm{Cu}^{2+}, \mathrm{Fe}^{3+}$ levels and significantly decreased content of $\mathrm{K}^{+}$in the yeast cell. However, ATP production measured by luminescence in the yeast cell exposed to $\mathrm{Cd}$ and $\mathrm{Ni}$ have not been analyzed prior to our experiments.

Using ATP bioluminescence-sensing assay we have found that addition of $1 \mathrm{mM}$ $\mathrm{Cd}$ or $1 \mathrm{mM} \mathrm{Ni}$ to the growth media of Schizosaccharomyces pombe resulted in marked increase of ATP levels in the cells (Table 2).

Table 2 Moles of ATP per cell treated with heavy metals compared to untreated control

\begin{tabular}{lccc}
\hline S. pombe & control & Cd [1mM] & Ni [1mM] \\
\hline ATP $[\mathbf{M}]$ per cell & $9.92 \times 10^{-16}$ & $2.90 \times 10^{-15}$ & $7.58 \times 10^{-15}$ \\
\hline
\end{tabular}

Furthermore, compared to the control group $(4.96 \pm 0.07 \mathrm{nM}$ ATP per sample), the cells exposed to Cd generated 2.93 times more ATP $(14.52 \pm 0.46 \mathrm{nM}$ ATP), and those treated with $\mathrm{Ni}$ exhibited even more dramatic increase of the luminescence signal indicating 7.64 times more ATP levels (37.90 $\pm 2.96 \mathrm{nM}$ ATP; Figure 1)

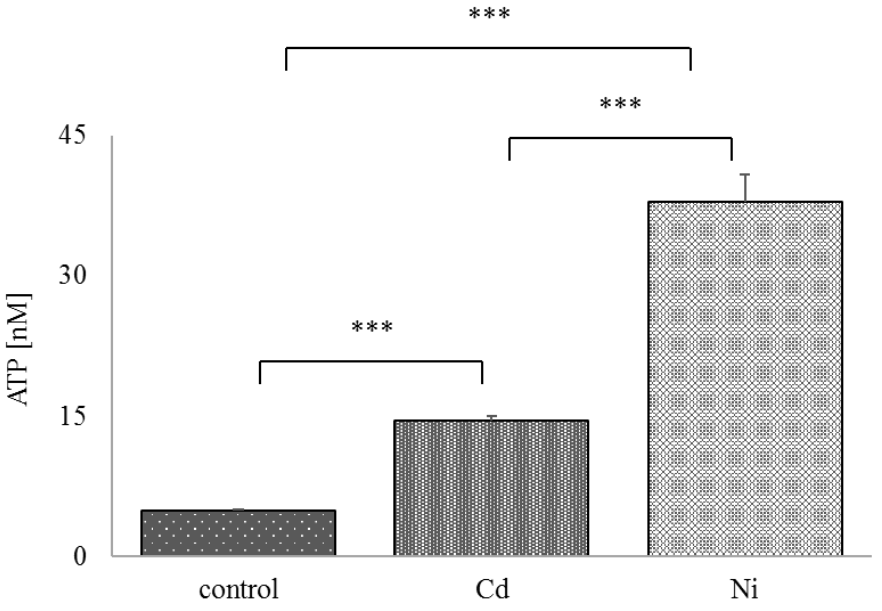

Figure 1 Heavy metal treatment causes marked elevation of ATP levels Comparison and graphical expression of ATP levels $[\mathrm{nM}]$ of untreated and heavy metal treated cells. The limit of statistical significance was set up at $\mathrm{P}<0.05\left(^{*}\right)$, $0.01(* *), 0.001(* * *)$.

The mechanisms of the impairing effects of $\mathrm{Ni}$ and $\mathrm{Cd}$ on biological systems is generation of reactive oxygen species (ROS) with subsequent oxidative injuries resulting also in mitochondrial dysfunction (Belyaeva et al., 2012; Maiti et al., 2018). However, despite the fact that mitochondria is a target site for heavy metal actions (Belyaeva et al., 2008), exact mechanisms of the metal-induced disturbances in mitochondrial function related to ATP production are not well 
understood. Currently, we have found that $S$. pombe cells exposed to high concentrations of $\mathrm{Cd}^{2+}(400 \mu \mathrm{M})$ and $\mathrm{Ni}^{2+}(1 \mathrm{mM})$ displayed a significant increase in $\mathrm{Ca}^{2+}$ content in comparison to the untreated cells (Pozgajova et al., 2019) Moreover, the results showed an enhanced stimulating impact of $\mathrm{Ni}^{2+}$ treatment on intracellular $\mathrm{Ca}^{2+}$ level elevation as compared to $\mathrm{Cd}^{2+}$ exposure which is consistent with the current findings revealing different ATP production levels between both groups of treated cells. Regarding enhanced impact of Ni on ATP production compared to $\mathrm{Cd}$ we speculate that this fact could be attributed to higher tolerance of $\mathrm{Ni}$ by the yeast due to its crucial role in certain enzymes biosynthesis. In $S$. pombe, the metal is specifically incorporated into nickeldependent enzyme such as urease (Ure2) catalyzing ATP-independent urea assimilation (Milne et al., 2015). Generally, mitochondria of the most biologica systems are capable of cytoplasmic $\mathrm{Ca}^{2+}$ sequestration to provide a transient calcium store for cell-protective mechanisms (Baretto et al., 2014). The research of Jouaville et al. (1999) showed that mitochondrial $\mathrm{Ca}^{2+}$ accumulation triggers an activation of the mitochondrial metabolic machinery leading to increased ATP synthesis in the organelle and consequently in the cytosol. Significantly increased concentrations of $\mathrm{Ca}^{2+}$ are invoked by the response of cells to heavy metalinduced excessive ROS generation subsequently stimulating $\mathrm{Ca}^{2+}$ release from the endoplasmic reticulum (ER) lumen followed by the massive influx of $\mathrm{Ca}^{2+}$ into the mitochondria. Although such $\mathrm{Ca}^{2+}$ overload is mostly associated with the induction of cell apoptosis (Bayley et al., 2018), $\mathrm{Ca}^{2+}$ overload also enhances mitochondrial activity leading to increased ATP production, causing along with decelerated metabolism, its accumulation within the cell. On the basis of al aspects we proposed that considerable higher levels of ATP detected in S. pombe cells exposed to $\mathrm{Cd}^{2+}$ and $\mathrm{Ni}^{2+}$ can be linked to the action of the heavy metalinduced ROS on cell (mitochondria) ion homeostasis.
Quantitation of ATP amounts becomes to have widespread implementation in various fields of studies such as physiology, metabolomics, or energetic studies. Moreover, over the last years the applications of luminescence measurements have been employed in ecological researches including microbial survival, microbial predation, plant pathogenicity, and reporting of gene expression in environmental samples (Prosser et al. 1996). However, the most common and practical use of an ATP bioluminescence assay is to evaluate the microbial quality of the food industry through testing of solid surfaces cleanness as part of general hazard analysis and critical control points (HACCP) measures (Carrascosa et al. 2012). With the use of previously described system of ATP measurement, we have evaluated the cleanness of the margarine production company after sanitation.

\section{ATP bioluminescence control of the cleanness of margarine company equipment surfaces}

Eleven samples from different parts of the margarine production line were analyzed using bioluminescence. As compared to the negative control, higher values for relative light or luminescence units (RLU) were recorded only in two evaluated samples. However, statistically significant differences $(p<0.05)$ have been found only between the control $\log _{10}$ relative luminescence units $\left(\log _{10}\right.$ RLU $2.88 \pm 0.55)$ and $\log _{10}$ RLU of the sample Nr. $1(4.84 \pm 0.11)$. This fact indicates a high level of cleanness of the margarine producing company devices except for a moderate contamination of the first representative sampling place. Calculated amounts of ATP in all investigated samples are shown in Table 2 .

Table 2 Evaluation of cleanness as marker of sanitation efficiency of the devices used for margarine production. Data are expressed as ATP [nM] levels in case of RLU values greater than RLU values of the negative control. RLU values equal or lower as those of the negative control were assessed as negative and represent high level of cleanness.

\begin{tabular}{lccccccccccc}
\hline Sample Nr. & $\mathbf{1}$ & $\mathbf{2}$ & $\mathbf{3}$ & $\mathbf{4}$ & $\mathbf{5}$ & $\mathbf{6}$ & $\mathbf{7}$ & $\mathbf{8}$ & $\mathbf{9}$ & $\mathbf{1 0}$ & $\mathbf{1 1}$ \\
\hline ATP [nM] & $0.132 \pm 0.0047$ & $0.00355 \pm 0.00013$ & neg. & neg. & neg. & neg. & neg. & neg. & neg. & neg. & neg.
\end{tabular}

ATP: adenosine 5'-phosphate; SD: standard deviation

Detection of foodborne pathogens by bioluminescence have been applied in many studies (Samkutty et al., 2001; Leon \& Albrecht, 2007; Luo et al., 2009, Hunter \& Lim, 2010; Lee et al., 2017). The method was also widely used for determination of the surface cleanliness in the food industry (Vilar et al., 2008; Osimani et al., 2014) and for monitoring of healthcare facilities (Aycicek et al., 2006; Willis et al., 2007; Boyce et al., 2009; Fukada et al., 2015). The results by Osimani et al. (2014) have revealed that ATP bioluminescence technology has proved to be a powerful tool for the real time monitoring of surface cleanliness at mass catering plants, to verify the correct application of Sanitation Standard Operating Procedures, and hence for their implementation/revision in the case of poor hygiene. The sensitivity, speed, and convenience of the evaluation process make this a powerful technique that is being applied in the risk assessment (Carrascosa et al. 2012). While, most of the test laboratories use portable luminometers for the ATP content determination, we used non-portable Glomax Multi+ Combined Spectro-Fluoro Luminometer located in our laboratory to tes the cleanness of the food producing company devices to approve suitability of the technique for such type of analyses. As the Glomax Multi+ Combined SpectroFluoro Luminometer is equipped with injectors allowing direct injection of the substrate separately to each sample prior to the measurement, acquired signal is almost free from any background noise, thus enabling very low ATP amoun detection. We assume that the presented ATP detection system is applicable for cleanness validation of food processing companies, as well as for detection of microbial predation or indirect determination of mitochondrial activity of tested biological system under environmental stress.

\section{CONCLUSION}

According to our results, the luminescence-based system of ATP measurement provides fast, cost effective, and reliable technique for determination of microorganism presence in the tested sample. Moreover, the technique is capable of detection of mitochondrial activity alterations under environmental stress conditions. However, to understand the precise mechanism of ATP flux under environmental stress, further analyses are required. Nevertheless, the ability to detect considerably low amount of microorganism occurrence in the tested sample makes it a powerful technique for cleanness assessment after periodical sanitation of food processing companies.

Acknowledgments: The work was supported by the project "AgroBioTech" of the Operational Programme Research and Development, Structural Funds of EU, contract number ITMS 26220220180

\section{REFERENCES}

Amari, T., Ghnaya, T., \& Abdelly, C. (2017). Nickel, cadmium and lead phytotoxicity and potential of halophytic plants in heavy metal extraction. South African Journal of Botany, 111, 99-110. https://doi.org/10.1016/j.sajb.2017.03.011

Aycicek, H., Oguz, U., \& Karci, K. (2006). Comparison of results of ATP bioluminescence and traditional hygiene swabbing methods for the determination of surface cleanliness at a hospital kitchen. International Journal of Hygiene and Environmental Health, 209(2), 203-206. https://doi.org/10.1016/j.ijheh.2005.09.007

Baretto, J. (2014). Application of Protein-based Biosensors in Detection of Novel Therapeutics and Environmental Monitoring (Doctoral dissertation, The Ohio State University).

Bayley, J. S., Winther, C. B., Andersen, M. K., Grønkjær, C., Nielsen, O. B., Pedersen, T. H., \& Overgaard, J. (2018). Cold exposure causes cell death by depolarization-mediated $\mathrm{Ca} 2+$ overload in a chill-susceptible insect. Proceedings of the National Academy of Sciences, 115(41), E9737-E9744. https://doi.og/10.1073/pnas.1813532115

Belyaeva, E. A., Dymkowska, D., Więckowski, M. R., \& Wojtczak, L. (2008). Mitochondria as an important target in heavy metal toxicity in rat hepatoma AS 30D cells. Toxicology and Applied Pharmacology, 231(1), 34-42. https://doi.org/10.1016/j.taap.2008.03.017

Belyaeva, E. A., Sokolova, T. V., Emelyanova, L. V., \& Zakharova, I. O. (2012) Mitochondrial electron transport chain in heavy metal-induced neurotoxicity: effects of cadmium, mercury, and copper. The Scientific World Journal, 2012 https://doi.org/10.1100/2012/136063

Betts, R., \& de Blackburn, C. W. (2009). Detecting pathogens in food In Foodborne Pathogens (pp. 17-65). Woodhead Publishing https://doi.org/10.1533/9781845696337.1.17

Bown, A. W., Hall, D. E., \& MacGregor, K. B. (2002). Insect footsteps on leaves stimulate the accumulation of 4-aminobutyrate and can be visualized through increased chlorophyll fluorescence and superoxide production. Plant Physiology, 129(4), 1430-1434. https://doi.org/10.1104/pp.006114

Boyce, J. M., Havill, N. L., Dumigan, D. G., Golebiewski, M., Balogun, O., \& Rizvani, R. (2009). Monitoring the effectiveness of hospital cleaning practices by use of an adenosine triphosphate bioluminescence assay. Infection Control \& Hospital Epidemiology, 30(7), 678-684. https://doi.org/10.1086/598243

Branchini, B. R., \& Southworth, T. L. (2017). A highly sensitive biosensor for ATP using a chimeric firefly luciferase. In Methods in enzymology (Vol. 589, pp. 351-364). Academic Press. https://doi.org/10.1016/bs.mie.2017.01.004

Carrascosa, C., Saavedra, P., Millán, R., Jaber, J. R., Pérez, E., Grau, R., ... \& Sanjuán, E. (2012). Monitoring of cleanliness and disinfection in dairies: 
Comparison of traditional microbiological and ATP bioluminescence methods. Food Control, 28(2),

$368-373$.

https://doi.org/10.1016/j.foodcont.2012.05.001

Cunningham, A. E., Rajagopal, R., Lauer, J., \& Allwood, P. (2011). Assessment of hygienic quality of surfaces in retail food service establishments based on microbial counts and real-time detection of ATP. Journal of Food Protection, 74(4), 686-690. https://doi.org/10.4315/0362-028X.JFP-10-395

Dostálek P., Brányik T. (2005): Prospects for rapid bioluminescent detection methods in the food industry - a review. Czech J. Food Sci., 23: 85-92.

Duracka, M., Lukac, N., Kacaniova, M., Kantor, A., Hleba, L., Ondruska, L., \& Tvrda, E. (2019). Antibiotics Versus Natural Biomolecules: The Case of In Vitro Induced Bacteriospermia by Enterococcus Faecalis in Rabbit Semen. Molecules, 24(23), 4329. https://doi.org/10.3390/molecules24234329

Ďúranová, H., Požgajová, M., Novotová, M., Lukáč, N., \& Kňažická, Z. (2019). Fission Yeast Schizosaccharomyces Pombe as a Model System for Ultrastructural Investigations Using Transmission Electron Microscopy. The Journal of Microbiology, Biotechnology and Food Sciences, 9(1), 160 https://doi.org/10.15414/jmbfs.2019.9.1.160-165

Eed, H. R., Abdel-Kader, N. S., El Tahan, M. H., Dai, T., \& Amin, R. (2016) Bioluminescence-sensing assay for microbial growth recognition. Journal of Sensors, 2016. https://doi.org/10.1155/2016/1492467

Elegado, B. F., Ramirez, T. J., Kawasaki, S., Alocilja, E. C., Yeasmin, S., Bari, L., \& Ukuku, D. (2016). Methods and technology for rapid and accurate detection of foodborne pathogens. Foodborne Pathogens and Food Safety. CRC Press, Boca Raton.

Feng, P. (2007). Rapid methods for the detection of foodborne pathogens: current and next-generation technologies. In Food Microbiology: Fundamentals and Frontiers, Third Edition (pp. 911-934). American Society of Microbiology. https://doi.org/10.1128/9781555815912.ch43

Fukada, T., Tsuchiya, Y., Iwakiri, H., \& Ozaki, M. (2015). Adenosine triphosphate bioluminescence assay for monitoring contamination of the working environment of anaesthetists and cleanliness of the operating room. Journal of infection prevention, 16(1), 8-13. https://doi.org/10.1177/1757177414553492 Fung, D. Y. C., Cox, N. A., \& Bailey, J. S. (1988). Rapid methods and automation in the microbiological examination of foods. Dairy and food sanitation (USA).

Hunter, D. M., \& Lim, D. V. (2010). Rapid detection and identification of bacterial pathogens by using an ATP bioluminescence immunoassay. Journal of food protection, 73(4), 739-746. https://doi.org/10.4315/0362-028X-73.4.739

Jan, T., Saadiya, R.A., \& Sharma, P. (2018). Rapid detection techniques of microorganisms. Journal of Pharmacognosy and Phytochemistry, 7(5), 16061611.

Jasson, V., Jacxsens, L., Luning, P., Rajkovic, A., \& Uyttendaele, M. (2010). Alternative microbial methods: An overview and selection criteria. Food microbiology, 27(6), 710-730. https://doi.org/10.1016/i.fm.2010.04.008

Jen, J. J. S., \& Chen, J. (Eds.). (2017). Food safety in China: Science, technology, management and regulation. John Wiley \& Sons.

Jouaville, L. S., Pinton, P., Bastianutto, C., Rutter, G. A., \& Rizzuto, R. (1999) Regulation of mitochondrial ATP synthesis by calcium: evidence for a long-term metabolic priming. Proceedings of the National Academy of Sciences, 96(24), 13807-13812. https://doi.org/10.1073/pnas.96.24.13807

Lazcka, O., Del Campo, F. J., \& Munoz, F. X. (2007). Pathogen detection: A perspective of traditional methods and biosensors. Biosensors and bioelectronics, 22(7), 1205-1217. https://doi.org/10.1016/j.bios.2006.06.036 Law, J. W. F., Ab Mutalib, N. S., Chan, K. G., \& Lee, L. H. (2015). Rapid methods for the detection of foodborne bacterial pathogens: principles, applications, advantages and limitations. Frontiers in microbiology, 5, 770 https://doi.org/10.3389/fmicb.2014.00770

Lee, N., Kwon, K. Y., Oh, S. K., Chang, H. J., Chun, H. S., \& Choi, S. W (2014). A multiplex PCR assay for simultaneous detection of Escherichia coli O157: H7, Bacillus cereus, Vibrio parahaemolyticus, Salmonella spp., Listeria monocytogenes, and Staphylococcus aureus in Korean ready-to-eat food. Foodborne pathogens and disease, 11(7), 574-580. https://doi.org/10.1089/fpd.2013.1638

Lee, J., Park, C., Kim, Y., \& Park, S. (2017). Signal enhancement in ATP bioluminescence to detect bacterial pathogens via heat treatment. BioChip Journal, 11(4), 287-293. https://doi.org/10.1007/s13206-017-1404-8

Leon, M. B., \& Albrecht, J. A. (2007). Comparison of adenosine triphosphate (ATP) bioluminescence and aerobic plate counts (APC) on plastic cutting boards. Journal of Foodservice, 18(4), 145-152.

Lomakina, G. Y., Modestova, Y. A., \& Ugarova, N. N. (2015). Bioluminescence assay for cell viability. Biochemistry (Moscow), 80(6), 701-713. https://doi.org/10.1134/S0006297915060061

López-Campos, G., Martínez-Suárez, J. V., Aguado-Urda, M., \& López-Alonso, V. (2012). Microarray detection and characterization of bacterial foodborne pathogens. Springer Science \& Business Media.

Luo, J., Liu, X., Tian, Q., Yue, W., Zeng, J., Chen, G., \& Cai, X. (2009) Disposable bioluminescence-based biosensor for detection of bacterial count in food. Analytical https://doi.org/10.1016/j.ab.2009.05.021
Mandal, P. K., Biswas, A. K., Choi, K., \& Pal, U. K. (2011). Methods for rapid detection of foodborne pathogens: an overview. Am. J. Food Technol, 6(2), 87102. https://doi.org/10.3923/ajft.2011.87.102

Maiti, A. K., Saha, N. C., Paul, G., \& Dhara, K. (2018). Mitochondrial respiratory chain inhibition and $\mathrm{Na}+\mathrm{K}+$ ATPase dysfunction are determinan factors modulating the toxicity of nickel in the brain of indian catfish Clarias batrachus L. Interdisciplinary toxicology, 11(4),

306. https://doi.org/10.2478/intox-2018-0030

Milne, N., Luttik, M. A. H., Rojas, H. C., Wahl, A., Van Maris, A. J. A., Pronk, J. T., \& Daran, J. M. (2015). Functional expression of a heterologous nickeldependent, ATP-independent urease in Saccharomyces cerevisiae. Metabolic engineering, 30, 130-140. https://doi.org/10.1016/j.ymben.2015.05.003

Osimani, A., Garofalo, C., Clementi, F., Tavoletti, S., \& Aquilanti, L. (2014) Bioluminescence ATP monitoring for the routine assessment of food contact surface cleanliness in a university canteen. International journal of environmental research and public health, 11(10), 10824-10837. https://doi.org/10.3390/ijerph111010824

Pozgajova, M., Navratilova, A., Arvay, J., Duranova, H., \& Trakovicka, A. (2019). Impact of cadmium and nickel on ion homeostasis in the yeast Schizosaccharomyces pombe. Journal of Environmental Science and Health, Part B, 1-8. https://doi.org/10.1080/03601234.2019.1673613

Prosser, J. I., Killham, K., Glover, L. A., \& Rattray, E. A. S. (1996). Luminescence-based systems for detection of bacteria in the environment. Critical reviews in biotechnology, 16(2), 157-183. https://doi.org/10.3109/07388559609147420

Samkutty, P. J., Gough, R. H., Adkinson, R. W., \& McGrew, P. (2001). Rapid assessment of the bacteriological quality of raw milk using ATP bioluminescence. Journal of food protection, 64(2), 208-212. https://doi.org/10.4315/0362-028X-64.2.208

Syguła-Cholewińska, J., Lech, T., Szostak-Kot, J., Błyskal, B., \& Sawoszczuk, T. ATP bioluminescence method in surface hygiene monitoring. PRODUCT PACKAGE, 77.

Valderrama, W. B., Dudley, E. G., Doores, S., \& Cutter, C. N. (2016) Commercially available rapid methods for detection of selected food-borne pathogens. Critical reviews in food science and nutrition, 56(9), 1519-1531. https://doi.org/10.1080/10408398.2013.775567

Vilar, M. J., Rodríguez-Otero, J. L., Diéguez, F. J., Sanjuán, M. L., \& Yus, E. (2008). Application of ATP bioluminescence for evaluation of surface cleanliness of milking equipment. International journal of food microbiology, 125(3), 357361. https://doi.org/10.1016/j.ijfoodmicro.2008.04.024

Wang, Y., \& Salazar, J. K. (2016). Culture-independent rapid detection methods for bacterial pathogens and toxins in food matrices. Comprehensive Reviews in Food Science and Food Safety, 15(1), 183-205. https://doi.org/10.1111/15414337.12175

Willis, C., Morley, R., Westbury, J., Greenwood, M., \& Pallett, A. (2007). Evaluation of ATP bioluminescence swabbing as a monitoring and training tool for effective hospital cleaning. British Journal of Infection Control, 8(5), 17-21. https://doi.org/10.1177/1469044607083604

Yanagida, M. (2002). The model unicellular eukaryote, Schizosaccharomyces pombe. Genome biology, 3(3), comment2003-1. https://doi.org/10.1186/gb-20023-3-comment2003

Zhao, X., Lin, C. W., Wang, J., \& Oh, D. H. (2014). Advances in rapid detection methods for foodborne pathogens. J. Microbiol. Biotechnol, 24(3), 297-312. https://doi.org/10.4014/jmb.1310.10013 